\title{
DISPARITAS ANTAR WILAYAH DAN PROVINSI DI INDONESIA SEBELUM DAN SESUDAH OTONOMI DAERAH
}

\author{
Yanuar \\ Fakultas Ekonomi Universitas Tarumanagara Jakarta \\ Email: yamuar@fetarumanagara.ac.id)
}

\begin{abstract}
Since the application of local autonomy in Indonesia in 2001, there have been more opportunities for the local governments to organize and manage their regions. It is meant to achieve regional development targets in improving the people's welfare and quality of life in accordance with each region's potentials. This research aims at measuring the disparity levels among various regions and provinces in Indonesia before and after the application of local autonomy. It used the descriptive method with secondary data from 1991 up to 2010, and the Gini coefficient analysis. This survey has concluded that the disparity levels before and after the application of local autonomy have remained high, both among the regional and provincial levels. During the period of conducting this research, the local autonomy has not significantly succeeded in reducing the disparity levels among regions and provinces in Indonesia.
\end{abstract}

Key words: local autonomy, disparity, region, province, welfare, quality of life.

\begin{abstract}
Abstrak: Sejak diberlakukan otonomi daerah di Indonesia tahun 2001, memberikan kesempatan atau peluang yang lebih besar kepada pemerintah daerah untuk mengurus dan mengatur daerahnya. Hal ini dalam rangka untuk mencapai tujuan pembangunan wilayah/daerah yaitu: mencapai kesejahteraan dan kualitas hidup masyarakat di daerahnya sesuai dengan potensi yang dimiliki wilayah/daerah masing-masing. Penelitian ini bertujuan untuk mengukur tingkat disparitas antar wilayah dan provinsi di Indonesia sebelum dan sesudah otonomi daerah. Metode yang digunakan adalah deskriptif dengan data sekunder tahun 1991 sd 2010 dan alat analisis Koefisien Gini. Penelitian ini menyimpulkan tingkat disparitas sebelum dan sesudah otonomi daerah tetap tinggi baik antar wilayah maupun pada tingkat provinsi. Pelaksanaan otonomi daerah selama periode penelitian ini belum berhasil mengurangi disparitas secara signifikan antar wilayah dan provinsi di Indonesia.
\end{abstract}

Kata kunci: otonomi daerah, disparitas, wilayah, provinsi, kesejahteraan, dan kualitas hidup

\section{PENDAHULUAN}

Pembangunan adalah suatu rangkaian upaya kegiatan dan proses perbaikan yang terencana, terpadu, bertahap dan berkesinambungan dalam berbagai bidang. Tujuan pembangunan dimaksudkan untuk menciptakan kualitas hidup manusia dengan memanfaatkan seluruh sumber daya yang ada secara optimal. Ruang lingkup pembangunan dimaksud tidak hanya dalam skala nasional,namun juga dalam skala regional/wilayah. 
Proses pembangunan negara kita terindikasi kuat terjadi trickle-up effect, hal ini dapat terlihat dari distribusi pendapatan yang mengalami penurunan pada kelompok 40 persen penduduk termiskin justru diikuti oleh kenaikan distribusi kue nasional yang dinikmati 20 persen kelompok terkaya dari 42,2 persen (2002) menjadi 48,42 persen (2011). Sementara kelompok 40 persen penduduk menengah mengalami penurunan kue nasional dari 36,9 persen (2002) menjadi 34,7 persen (2011).

Ketimpangan distribusi PDRB terhadap PDB antar daerah penting untuk diteliti karena gravitasi aktivitas ekonomi Indonesia masih cenderung terkonsentrasi secara geografis ke kawasan barat Indonesia (KBI) selama lebih dari lima dasawarsa terakhir. Betapa tidak, data BPS hingga triwulan IV 2012 menunjukkan, struktur perekonomian Indonesia secara spasial masih didominasi kelompok provinsi di Pulau Jawa yang memberikan kontribusi tẻrhadap produk domestik bruto (PDB) sekitar 57,5 persen, diikuti Pulau Sumatera sckitar 23,9 persen. Kawasan Timur Indonesia (KTT) hanya kebagian sisanya, sekitar 18,6 persen. Dengan kata lain, ketimpangan antar wilayah dan pulau terus terjadi (BPS diolah).

Mengusahakan kesejahteraan dan kemakmuran rakyat adalah suatu tujuan pembangunan. Menurut Chenery dan Srinivasan (1988) pembangunan diukur dengan kualitas hidup (the quality of life). Todaro dan Smith (2006: 28-29) proses pembangunan di semua masyarakat paling tidak harus memiliki tiga tujuan sebagai berikut:

1. Peningkatan ketersediaan serta perluasan distribusi berbagai barang kebutuhan hidup (kebutuhan pokok) seperti: pangan, sandang, papan, kesehatan, dan perlindungan keamanan.

2. Peningkatan standar hidup, yang tidak hanya berupa peningkatan pendapatan, tetapi juga meliputi penambahan penyediaan lapangan kerja, perbaikan kualitas pendidikan, serta peningkatan perhatian atas nilai-nilai kultural dan kemanusiaan, yang kesemuanya itu tidak hanya memperbaiki kesejahteraan material, melainkan juga menumbuhkan harga díri pada pribadi dan bangsa yang bersangkutan.

3. Perluasan pilihan-pilihan ekonomi dan sosial bagi setiap individu serta bangsa secara keseluruhan, yakni membebaskan mereka dari sikap menghamba dan ketergantungan, bukan hanya terhadap orang atau negara-bangsa lain, namun juga terhadap setiap kekuatan yang berpotensi merendahkan nilai-nilai kemanusiaan mereka.

Sejak diberlakukanUU N0.22/1999 dan UU No.25/1999 yang dirubah menjadi UU No. 32 dan 33 tahun 2004 yang memberikan kesempatan atau membuka peluang yang lebih besar bagi pemerintah daerah untuk mengurus dan mengatur daerahnya dalam rangka mencapai kesejahteraan dan kualiatas hidup masyarakatnya sesuai dengan potensi dserah masing-masing. Sebagian daerah bisa memanfatkan otonomi daerah ini dan sebagian lagi belum dapat memanfaatkannya dengan berbagai kendala atau hambatan yang dihadapi, sesuai dengan apa yang dinyatakan oleh Matsui (2005) bahwa hambatan yang paling besar sering kali muncul pada pemahaman yang terbatas terhadap desentralisasi oleh pemerintahan wilayah dan pemerintahan lokal sehingga malah mengakibatkan terjadinya kesenjangan wilayah.

Dari hasil studi dampak pemekaran daerah (Bappenas dan UNDP, 2008) pembagian potensi ekonomi yang tidak merata dan beban penduduk miskin yang lebih tinggi pada daerah pemekaran juga memberikan kontribusi pada ketimpangan pembangunan antar wilayah. Ketimpangan (disparitas) pembangunan antar wilayah merupakan aspek yang umum terjadi pada kegiatan ekonomi suatu daerah. Adanya ketimpangan antar wilayah menunjukkan perbedaan tingkat pembangunan dan tingkat kesejahteraan. Ketimpangan 
antar wilayah sering sekali menjadi permasalahan yang serius.Beberapa daerah mencapai pertumbuhan yang cepat (developed region), sementara beberapa daerah lain mengalami pertumbuhan yang lambat (underdeveloped region).

Berdasarkan latar belakang dalam uraian diatas maka perumusan masalah dalam penelitian ini adalah sebagai berikut: (1) Bagaimana tingkat disparitas antar wilayah di Indonesia sebelum dan sesudah otonomi Daerah?; (2) Bagaimana tingkat disparitas antar provinsi di Indonesia sebelum dan sesudah otonomi Daerah?

Manfaat PDB dan PDRB. Salah satu indikator yang dapat digunakan untuk mengukur kinerja perekonomian suatu wilayah pada suatu periode tertentu adalah Produk Domestik Bruto/Produk Domestik Regional Bruto (PDB/PDRB). Menurut BPS pemanfaatan data PDRB sudah semakin meluas dan sangat dimensional menyangkut kepentingan pemerintah dan publik secara umum. Selain in, PDB/PDRB juga dipakai dalam proses kenegaraan dan instrumen kebijakan antara lain:

Pertumbuhan ekonomi digunakan untuk menilai: (1) apakah ekonomi sedang mengalami stagnasi, (2) apakah sektor riil masih bergerak, (3) apakah pertumbuhan ekonomi berkualitas dalam arti mampu mengurangi kesenjangan, pengangguran dan kemiskinan. b. Besaran PDB/PDRB telah masuk dalam proses kenegaraan dan legislasi yaitu digunakan untuk: (1) asumsi makro/Rancangan Anggaran Pendapatan dan Belanja Negara (RAPBN), (2) patokan defisit anggaran $(1,0-2,0$ persen terhadap PDB), (3) efektivitas kebijakan fiskal pernerintah dan produktivitas penggunaan aset-aset daerah, (4) efektivitas penerimaan pajak dan retribusi (tax ratio), 13-15 persen dari PDB, dan seterusnya. c. Data PDRB untuk kabupaten/kota juga digunakan sebagai salah satu komponen dalam pengalokasian Dana Alokasi Umum (DAU), disamping data penduduk, luas wilayah, Indeks. Pembangunan Manusia (IPM) dan Indeks Kemahalan Konstruksi (IKK). d. Postur PDRB didalami untuk melihat peranan masing-masing sektor, sumber pertumbuhan dan skala usaha (Usaha Kecil dan Menengah/UKM). e. Dan yang paling klasik, PDRB digunakan untuk melihat keterbandingan kemajuan ekonomi antar daerah, kesenjangan ekonomi antar daerah dan antar sektor, dan potensi yang masih bisa dikembangkan untuk meningkatkan perekonomian di masing-masing daerah.

Oleh karena itu, berdasarkan uraian di atas, besaran PDB/PDRB dapat digunakan sebagai indikator didalam menilai kinerja perekonomian, terutama yang dikaitkan dengan kemampuan suatu daerah dalam mengelola sumber daya yang dimilikinya. Salah satu manfaat dari data PDRB adalah untuk mengetahui nilai produk yang dihasilkan oleh seluruh faktor produksi, besarnya laju pertumbuhan ekonomi dan struktur perekonomian pada sảtu periode di suatu daerah tertentu. Besaran PDRB bervariasi antara daerah satu dengan yang lainnya.

Hal ini terjadi karena adanya perbedaan dalam: (a) potensi sumber daya alam, (b) sarana dan prasarana, (c) modal yang tersedia, dan (d) kemampuan sumber daya manusia yang dimiliki oleh daerah tersebut,

Ketimpangan Pendapatan. Ketimpangan menggambarkan distribusi pendapatan antar penduduk dalam suatu wilyah atau distribusi PDRB antar wilayah dalain negara dalam jangka waktu tertentu. Ukuran ketimpangan antar wilayah, dilakukan dengan berbagai pendekatan yaitu: Pertama, ukuran ketimpangan pembangunan antar wilayah dengan menggunakan Produk Domestik Regional Bruto (PDRB) per kapita dan jumlah penduduk sebagai data dasar dipelopori oleh Williamson 1996 yang dikenal dengan Williamson 
Index. Kedua Theil Index. Data yang digunakan untuk ini sama dengan Williamson Index yaitu Regional Bruto (PDRB) per kapita dan jumlah penduduk. Penafsiran kedua index tersebut juga sama yaitu yaitu mendekati 0 berarti semakin sangat merata dan mendekati 1 semakin sangat timpang. Theil Index sebagai ukuran ketimpangan mempunyai beberapa kelebihan (Syafrizal 2008; 108-109) yaitu: Pertama, indeks ini dapat menghitung ketimpangan dalam daerah dan antar daerah secara sekaligus, sehingga cakupan analisa menjadi lebih luas. Kedua, dengan menggunakan indeks ini dapat pula dihitung kontribusi (dalam persentase) masing-masing daerah terhadap ketimpangan pembangunan wilayah secara keseluruhan sehingga dapat memberikan implikasi kebijakan yang cukup penting. Ketiga, Indeks Gini untuk mengukur ketimpangan distribusi pendapatan antargolongan pendapatan antar penduduk dalam suatu wilayah atau ketimpangan PDRB antar wilayah yang diukur dengan indeks Gini dengan nilai antar 0 (setiap orang atau wilayah mempunyai pendapatan yang sama) dan 1 (satu orang/wilyah memiliki seluruh pendapatan sedangkan yang lain pendapatnya nol) dan berapa kue nasional yang dinikmati 40 persen golongan pendapatan terendah. Keempat, Bank Dunia (World Bank) mengelompokan distribusi pendapatan menjadi 3 kategori yaitu: (1) jumlah proporsi yang diterima oleh $40 \%$ penduduk lapisan bawah, (2) jumlah proporsi yang yang diterima $40 \%$ penduduk lapisan sedang, (3) jumlah proporsi yang diterima $20 \%$ penduduk lapisan tinggi.

Berdasarkan katagori di atas maka tingkat ketimpangan pendapatan oleh Bank Dunia dikelompokan menjadi 3 macam yaitu: (1) Ketimpangan pendapatan tinggi (highly inequality); (2) Ketimpangan pendapatan sedang (moderate inequality); (3) Ketimpangan pendapatan rendah (low inequality).

Hipotesis kurva U- terbalik Kuznet (U-Shape Curve) yang dikemukakan oleh Kuznet (Todaro 2006: 253-258) bahwa pada tahap awal pertumbuhan ekonomi, distribusi pendapatan cenderung memburuk (disparitas yang tinggi) namun pada tahap berikutnya distribusi pendapatan cenderung membaik, Data World Bank perkiraan distribusi pendapatan 15 negara dekade 1990-an sd 2000-an memperlihatkan parahnya tingkat ketimpangan (disparitas), tetapi hasil penelitian pada 35 negara Amerika Latin dan Asia, Field dan Jakubson menemukan hanya Brasil menunjukkan kurva U- terbalik. Sebaliknya data untuk Hongkong dan Singapura memperlihatkan kurva berbentuk U. Lonondro menemukan pola U terbalik untuk Kolombia dan Oshima tidak menemukan apapun untuk kasus sejumlah negara Asia.

Todaro (2003) pemerataan yang lebih adil (disparitas yang rendah) di negara berkembang merupakan syarat untuk menunjang pertumbuhan ekonomi. Semakin tinggi ketimpangan antar wilayah maka akan semakin besar dampaknya terhadap tingkat pertumbuhan ekonomi.

Menurut Myrdal (1957) menjelaskan ketimpangan antar wilayah dengan menggunakan spread effect dan backwash effect. Spread effect sebagai pengaruh yang menguntungkan (favorrable effect) dimana terjadinya penyebaran kegiatan investasi dan transfer teknologi dari pusat pertumbuhan ke wilayah sekitar. Sedangkan backwash effect adalah terjadinya aliran modal dan tenaga kerja trampil dari daerah sekitar ke pusat pertumbuhan (wilayah inti). Hal ini mengakibatkan terjadinya kekurangan modal dan tenaga kerja trampil di wilayah sekitar yang sebenarnya sangat dibutuhkan untuk pembangunan pada wilayah tersebut. Terjadinya ketimpangan menurut Myrdal disebabkan oleh backwash effect tersebut dan perpindahan aliran modal dan tenaga kerja trampil ke daerah maju (inti) akan meningkatkan ketimpangan antar wilayah tersebut. 
Syafrizal (2008) ketimpangan ini pada dasarnya disebabkan oleh:

1. Perbedaan kandungan sumber daya alam. Perbedaan kandungan sumber daya alam mendorong timbulnya ketimpangan pembangunan antar wilayah. Perbedaan kandungan antar wilayah di Indonesia ternyata cukup besar. Ada daerah yang mempunyai cadangan minyak dan gas alam, tetapi daerah lain tídak mempunyai. Ada daerah yang mempunyai deposit batu bara yang cukup besar sementara daerah lain tidak ada.

2. Perbedaan Kondisi Demografis. Perbedaan kondisi demografis yang cukup besar antar wilayah mendorong perbedaan tingkat pertumbuhan yang akhirnya menciptakan ketimpangan pembangunan. Kondisi demografis yang dimaksud adalah meliputi perbedaan tingkat pertumbuhan dan struktur kependudukan, perbedaan tingkat pendidikan dan kesehatan, perbedaan kondisi ketenaga kerjaan dan perbedaan dalam tingkah laku dan kebiasaan serta etos kerja yang dimiliki masyarakat daerah tersebut.

Kondisi demografis akan mempengaruhi produktivitas kerja masyarakat pada akhirnya mempengaruhi pertumbuhan dan ketimpangan pembangunan.

3. Perbedaan Mobilitas Barang dan Jasa. Mobilitas barang dan jasa terdiri dari: kegiatan perdagangan dan migrasi penduduk antar wilayah. Perbedaan mobiltas barang dan jasa akan mempengaruhi produksi dan pertumbuhan antar wilayah yang berdampak terhadap ketimpangan pembangunan antar willayah.

4. Konsentrasi Kegiatan Ekonomi Wilayah. Terjadinya konsentrasi kegiatan ekonomi yang cukup tinggi pada wilayah tertentu jelas akan mempengaruhi ketimpangan pembangunan antar wilayah. Pertumbuhan ekonomi wilayah yang mempunyai konsentrasi ekonomi yang cukup besar cenderung akan lebih cepat dari daerah yang konsentrasi ekonominya rendah.

5. Alokasi Dana Pembangunan Antar Wilayah. Investasi merupakan salah satu unsur penting dalam pertumbuhan ekonomi suatu wilayah. Karena itu daerah yang dapat alokasi investasi yang lebih besar dari pemerintah, atau dapat menarik investasi swasta yang besar cenderung mempunyai tingkat pertumbuhan ekonomi yang lebih cepat.

Menurut Anwar (2005) beberapa hal yang menyebabkan terjadinya ketimpangan (disparitas) pembangunan antar daerah adalah: (1) Perbedaan karakteristik limpahan sumber daya; (2) Perbedaan demografi; (3) Perbedaaan kemampuan sumber daya manusia; (4) Perbedaan potensi lokasi; (5) Perbedaan dari aspek aksesibilitas dan kekuasaan dalam pengambilan keputusan; (6) Perbedaan dari aspek potensi pasar.

Akibat dari faktor-faktor tersebut maka dalam suatu wilayah akan terdapat beberapa macam karakteristik wilayah yang bisa dilihat dari aspek kemajuannya yaitu:

1) Wiayah Maju, wilayah yang telah berkembang yang biasanya dicirikan sebagai pusat pertumbuhan. Di wilayah ini terdapat pemusatan penduduk, industry, pemerintahan. dan sekaligus pasar potensial, Selain itu dicirikan oleh tingkat pendapatan yang tinggi, tingakat pendidikan dan kualiatas sumber daya yang tinggi dan struktur ekonomi yang secara relatif didominasi oleh sector industry dan jasa.

2) Wilayah Sedang Berkembang, wilayah sedang berkembang bisanya dicirikan oleh pertumbuhan yang cepat dan biasanya wilayah penyangga dari daerah maju, karena itu mempunyai asesibilitas yang baik terhadap daerah maju.

3) Wilayah Belum Berkembang, wilayah belum berkembang dicirikan oleh tingkat pertumbuhan yang masih rendah baik secara absolute maupun secara relatif namun memilki potensi sumber daya alam yang belum dikelola atau dimanfaatkan. Wilayah 
ini mempunyai tingkat kepadatan penduduk yang relative rendah dan tingkat pendidikan yang relative rendah.

4) Wiayah Tidak Berkembang, wilayah tidak berkembang dicirikan oleh dua hal yakni: (a) wilayah tersebut memang tidak mempunyai potensi yang baik, potensi sumber daya alam maupun potensi lokasi sehingga secara alamiah sulit berkembang dan tumbuh, (b) wilayah tersebut sebenarnya memiliki potensi, baik sumber daya alam atau lokasi maupun memiliki keduanya tetapi tidak dapat berkembang karena tidak memperoleh kesempatan, dan cenderung dieksploitasi oleh wilayah yang lebih maju. Wilayah ini dicirikan oleh tingkat kepadatan penduduk yang jarang, kualiatas sumber daya manusia yang rendah, tingkat pendapatan yang rendah, tidak memiliki infrastuktur yang lengkap, dan tingkat aksesibilitas yang rendah.

Pendapat Syafrizal dan Anwar menekankan peranan pada perbedaan sumber daya, potensi lokasi (konsentrasi kegiatan ekonomi) dan geografi yang menyebabkab terjadinya disparitas pertumbuhan regional antar wilayah, sedangkan menurut (Glaeser, 2000), perbedaan pertumbuhan ekonomi regional ditentukan oleh berbagai aspek perubahan dalam suatu region (wilayah) yang meliputi: (1) Perubahan teknologi dan inovasi; (2) Human capital, penelitian (embracing research) dan pendidikan; (3) Aglomerasi dan ekternalitas; (4) Knowledge spill over, melibatkan wirausahawan dan perusahaan baru; (5) Spesialisasi ektoral dan diversifikasi.

Menurut Shaffer (1989), pertumbuhan ekonomi per kapita suatu wilayah, ditentukan oleh tingkat kemajuan teknologi dari masing-masing wilayah. Konsekuensinya adalah keseimbangan perekonomian antar wilayah ditentukan oleh kondisi tingkat kemajuan antar wilayah. Walaupun pertumbuhan penduduk antar wilayah sama, tetapi tingkat kemajuan teknologi antar wilayah tersebut berbeda, maka tidak akan terjadi keseimbangan pertumbuhan antar wilayah. Jika keseimbangan pertumbuhan antar wilayah terjadi (kondisi pareto optimal) maka akan tercapai keseimbangan perekonomian wilayah. Hal ini bisa dianggap sebagai suatu kondisi yang efisien bagi sistem perekonomian wilayah tersebut.

Kondisi yang efisien pada suatu perkonomian wilayah tidak selalu tercapai, karena perbedaan faktor produksi yang tersedia pada setiap wilayah. Hal ini akan menyebabkan produktivitas antar wilayah akan bebeda yang pada akhimya menyebabkan terjadi disparitas (ketimpangan) antar wilayah baik diukur dalam proporsi PDRB terhadap PDB maupun koefisien Gini antar wilayah atau provinsi.

Permasalahan ketimpangan/kesenjangan pembangunan di Indonesia antara lain disebabkan adanya konsentrasi kegiatan ekonomi di suatu wilayah, perbedaan alokasi investasi, mobilitas faktor-faktor produksi antar daerah rendah, dan adanya hambatan perdagangan antar daerah

Hasil penelitian dari Alisyahbana dan Akita (2002) dengan menggunakan Theil Index untuk mengukur alat ketimpangan pembangunan antar Propinsi dan antar Kabupaten yang memberikan hasil bahwa ketimpangan pembangunan antar propinsi berkaitan langsung dengan ketimpangan pembangunan antar kabupaten.

\section{METODE}

Penelitian ini menggunakan data sekunder yang diperoleh dari beberapa sumber publikasi sebelum dan sesudah otonomi daerah yaitu tahun 1991 sd 2010. Adapun yang dimaksud dengan wilayah (pembagian wilayah) dalam penelitian berdasarkan pembagian wilayah 
yang dilakukan oleh Bappenas sebagai berikut ini: Jawa-Bali, Sumatera, Kalimantan, Sulawesi, Maluku, Nusa Tenggara dan Papua. Sedangkan yang dimaksud dengan provinsi dalam penelitian ini adalah: meliputi semua pada provinsi dan wilayah di Indonesia, kecuali provinsi yang sudah terpisah dari wilayah Indonesia seperti provinsi Timor Timur dan provinsi - provinsi yang baru dimekarkan di Indonesia pada kurun waktu penelitian 1991 hingga 2010 seperti: provinsi Banten, provinsi Bangka Belitung, provinsi Kepulauan Riau, provinsi Gorontalo, provinsi Sulawesi Barat, provinsi Maluku Utara, dan provinsi Papua Barat karena tidak memiliki data yang sama jangka waktunya dengan provinsi lainnya. Model analisis yang digunakan untuk menganalisis disparitas antar wilayah dan provinsi adalah menggunakan koefisien Gini yang dapat dihitung dengan rumus:

$$
\mathrm{G}=1-\Sigma_{1}{ }^{n}\left(\mathrm{X}_{i+1}-\mathrm{X}_{\mathrm{i}}\right)\left(\mathrm{Y}_{\mathrm{i}}+\mathrm{Y}_{\mathrm{i}+1}\right)
$$

Dimana: $\mathrm{G}=$ Koefisien Gini; $\mathrm{X}_{1}=$ Proporsi kumulatif populasi (wilayah) dalam kelas I; $Y_{k}=$ Proporsi kumulatif pendapatan dalam kelas $\mathrm{i}$

Nilai koefisien Gini antara 0 dan 1 , untuk menjelaskan tingkat pemerataan. Jika nilai koefisien mendekati 0 maka distribusi pendapatan semakin merata, dan jika nilai koefisien mendekati 1 maka berarti distribusi pendapatan semakin merata.

Pengolahan data dilakukan dengan menggunakan software (Had2Know 2010-2013)

\section{HASIL DAN PEMBAHASAN}

Berdasarkan distribusi persentase Produk Domestik Regional Bruto (PDRB) sebelum otonomi daerah setiap wilayah Jawa-Bali, Sumatera, Kalimantan, Sulawesi, Maluku, Nusa Tenggara dan Papua terhadap Produk Domestik Bruto (PDB) terlihat distribusi (persentase) yang tidak merata.

Dari gambar 1 berikut ini secara eksplisit terlihat jelas distribusi persentase PDRB antar wilayah sebelum otonomi daerah: Jawa-Bali, Sumatera, Kalimantan, Sulawesi, Maluku, Nusa Tenggara dan Papua. Konsetrasi tertinggi distribusi persentase PDRB ratarata terhadap PDB tahun 1991sd 2000 (sebelum otonomi) terdapat di wilayah Jawa dan Bali yaitu sebesar 60,40 persen.

Hal ini disebabkan empat besar provinsi dengan jumlah PDRB terbesar di Indonesia ada di pulau Jawa seperti: DKI Jakarta, Jawa Barat, Jawa Timur, dan Jawa Tengah. DKI Jakarta sebagai pusat pemerintahan, perdagangan dan jasa, sedangkan untuk provinsi Jawa Barat, Jawa Tengah dan Jawa Timur lebih banyak didominasi oleh aktivitas sektor industri pengolahan, perdagangan, pertanian. Konsentrasi tersebut menarik modal, tenaga kerja, dan investasi dari daerah-daerah lain masuk ke pulau Jawa atau terjadinya backwash effect untuk menghasilkan barang dan jasa.Hal inilah yang menyebabkan konsentrasi distribusi PDRB terpusat di pulau Jawa.

Distribusi persentase rata-rata PDRB terhadap PDB berikutnya setelah wilayah Jawa dan Bali adalah wilayah Sumatera sebesar 23,05 persen. Kontribusi sektor yang dominan adalah sektor pertanian, sektor pertambangan, dan sektor industri pengolahan. Peringkat ketiga yang berkontribusì rata-rata PDRB terhadap pembentukkan PDB adalah wilayah Kalimantan yaitu sebesar 8,8 persen. Sektor-sektor yang dominan dalam pembentukan PDRB di wilayah Kalimantan adalah sektor pertambangan (minyak, gas dan batu bara) dan sektor perkebunan. Wilayah dengan distribusi persentase rata-rata PDRB terhadap PDB sebelum otonomi daerah terendah adalah wilayah Maluku sebesar 0,68 persen. 


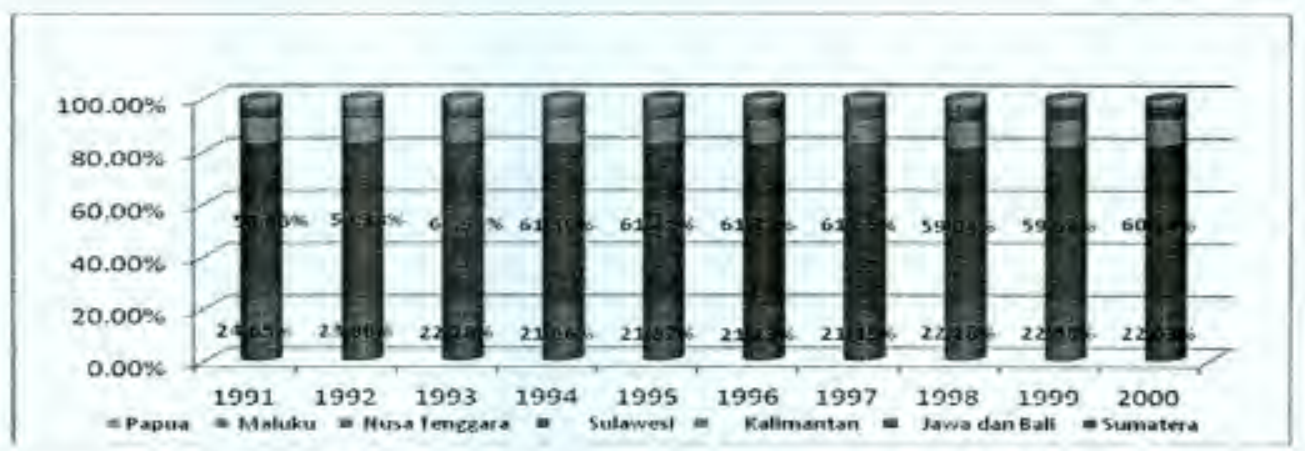

Gambar 1. Distribusi Persentase PDRB Harga Berlaku Menurut Wilayah Sebelum Otonomi Daerah (Tahun 1991-2000)

Sumber: BPS (diolah)

Sesudah otonomi daerah (2001 sd 2010) seperti terlihat pada gambar 2 distribusi persentase PDRB terhadap PDB antar wilayah konsentrasi tertinggi tetap pada wilayah Jawa dan Bali tetapi sudah mengalami sedikit penurunan dari 60,40 persen menjadi sebesar 60,28 persen. Distribusi persentase rata-rata PDRB terhadap PDB berikutnya setelah wilayah Jawa dan Bali tetap ditempati oleh wilayah Sumatera dari 23,05 persen sebelum otonomi daerah menjadi sebesar 22,51 persen sesudah otonomi daerah . Wilayah Kalimantan masih tetap menempati peringkat ketiga dengan kontribusi rata-rata PDRB terhadap PDB mengalami penurunan 8,8 persen menjadi 8,4 persen.

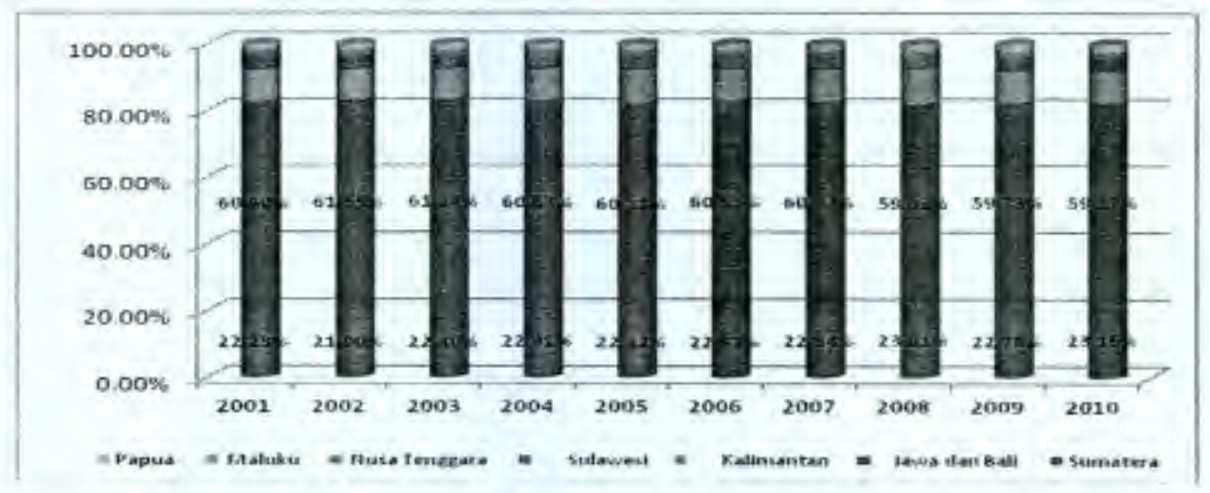

Gambar 2. Distribusi Persentase PDRB Harga Berlaku Menurut Wilayah Sesudah Otonomi Daerah (Tahun 2001-2010)

Sumber: BPS (diolah)

Peningkatan kontribusi rata-rata PDRB terhadap PDB terjadi pada wilayah Nusa Tenggara dan Wilayah Maluku sebelum otonomi daerah kedua wilayah memberikan kontribusi masing-masing sebesar 1 persen. Setelah otonomi daerah kedua wilayah mengalami peningkat kontribusinya menjadi 2 persen. Wilayah dengan distribusi persentase rata-rata PDRB terhadap PDB sebelum otonomi daerah terendah tetap wilayah Maluku.

Ketimpangan Antar Wilayah. Ketimpangan/kesenjangan pembangunan antar wilayah/provinsi disebabkan adanya konsentrasi kegiatan ekonomi di suatu wilayah/provinsi, perbedaan alokasi investasi (sektor perdagangan, industri pengolahan 
dan jasa), mobilitas faktor-faktor produksi (modal dan tenaga kerja) antar wilayah/provinsi dari daerah maju ke daerah belum maju atau terjadi backwash effect dan perbedaan kualitas infrastruktur serta kualitas human capital antar wilayah/provinsi.

Perbedaan tersebut mengakibatkan jumlah barang dan jasa yang dihasilkan antar wilyah/provinsi atau nilai PDRB akan berbeda antar wilayah/provinsi. Hal ini selanjutnya akan menyebabkan distribusi PDRB antar wilayah/provinsi akan mengalami ketimpangan.

Hasil perhitungan koefisien Gini antar wilayah di Indonesia pada tahun 1991 sd 2000 atau sebelum otonomi daerah seperti yang terlihat pada gambar 3 nilai rata-rata koefisien Gini sebelum otonomi daerah adalah 0.5311. Koefisien Gini wilayah sebelum otonomi daerah nilainya berfluktuasi tajam dengan nilai terendah 0,5118 pada tahun 1991 dan tertinggi sebesar 0,5711 pada tahun 1994 tetapi dengan tren yang meningkat sepeti terlihat pada gambar 3 .

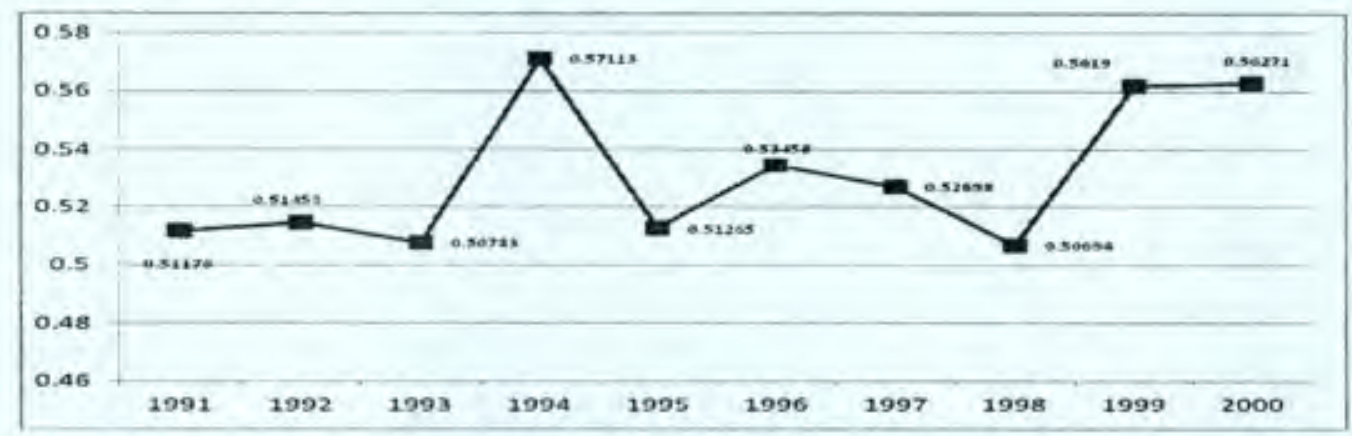

Gambar 3. Koefisien Gini Antar Wilayah di Indonesia Sebelum Otonomi Daerah Tahun (1991-2000)

Sumber: BPS (diolah)

Nilai koefisien Gini tahun 2001 sd 2010 (sesudah otonomi daerah) dengan rata-rata sebesar 0.515814 dengan nilai tertinggi adalah 0,5376 pada tahun 2001 dan nilai terendah adalah 0,4708 . Secara garis tren nilai koefisien Gini sesudah otonomi daerah memperlihatkan garis yang menurun dengan fluktuasi yang cukup tajam. Hal ini dapat terlihat pada gambar 4. Terjadinya ketimpangan antar wilayah dan provinsi di Indonesia disebabkan oleh backwash effect tersebut dan perpindahan aliran modal dan tenaga kerja trampil ke daerah maju (inti). Hal ini mendukung teori Myrdal.

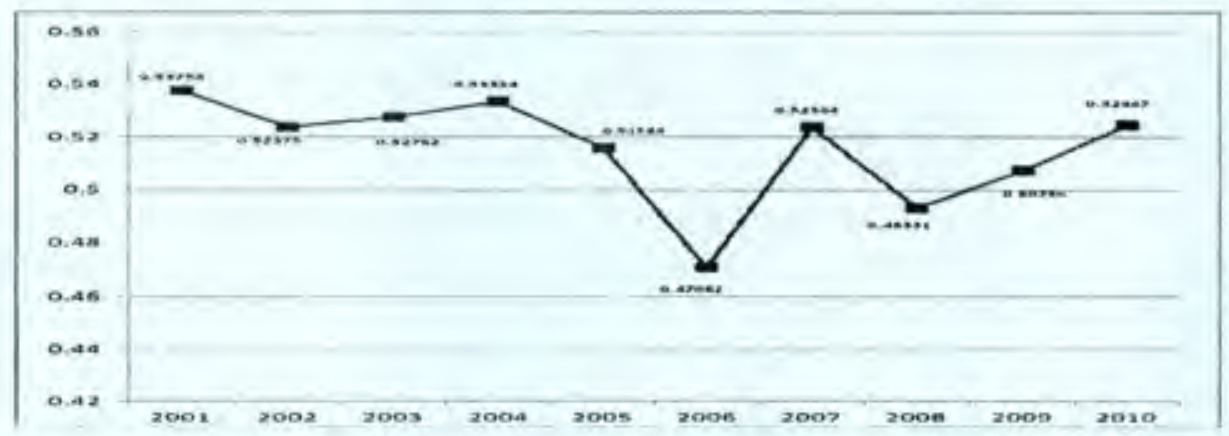

Gambar 4. Koefisien Gini Antar Wilayah di Indonesia Sesudah Otonomi Tahun Daerah Tahun (2001-2010)

Sumber:BPS (diolah) 
Ketimpangan Antar Provinsi. Ketimpangan antar provinsi di Indonesia sebelum otonomi daerah (tahun 1991 sd 2000) dengan nilai-rata adalah sebesar 0,5358 dengan nilai terendah 0,5034 pada tahun 1991 dan nilai tertinggi adalah 0,5803 pada tahun 1994 . Garis tren koefisien Gini sebelum otonomi daerah berfluktuasi relatif tajam dan memperlihatkan tren yang meningkat. Hal ini dapat terlihat pada tabel 5 .

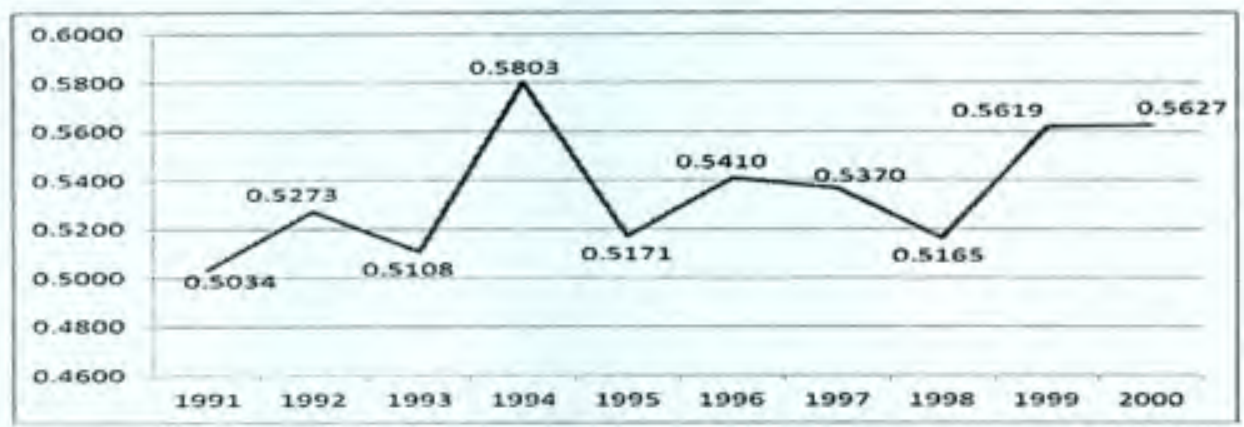

Gambar 5. Koefisien Gini Antar Provinsi di Indonesia Sebelum Otonomi Daerah Tahun (1991-2000)

Sumber: BPS (diolah)

Ketimpangan distribusi PDRB antar provinsi (koefisien Gini) sesudah otonomi daerah (tahun 2001 sd 2010) memperlihatkan nilai rata-rata sebesar 0,503 dengan nilai terendah adalah sebesar 0,426 pada tahun 2006 dan nilai tertinggi adalah 0,537 pada tahun 2001 . Garis tren koefisien Gini sesudah reformasi memperlihatkan tren yang menurun. Hal ini bisa terlihat pada tabel 6 .

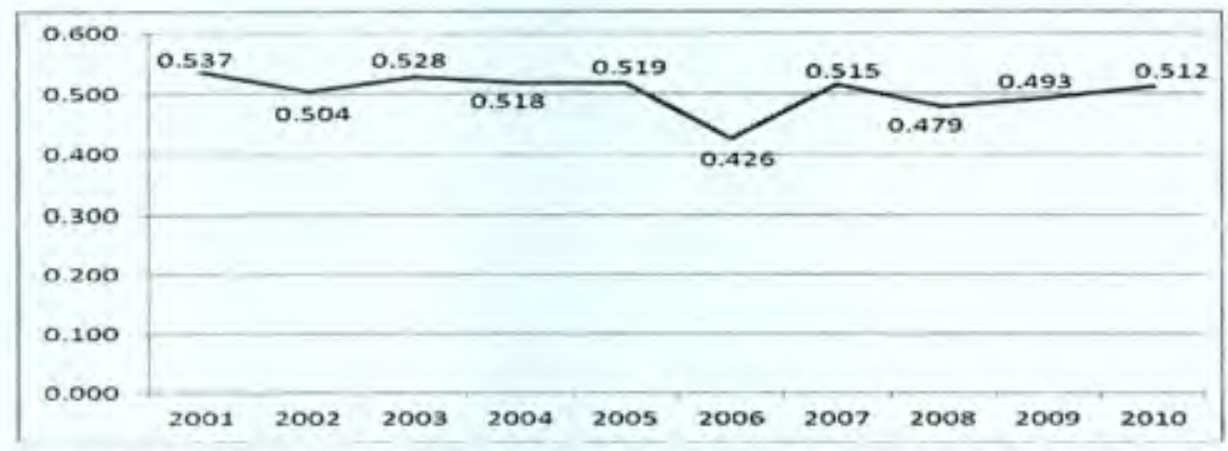

Gambar 6. Koefisien Gini Antar Provinsi di Indonesia Sesudah Otonomi Daerah Tahun (2001-2010)

Sumber: BPS (diolah)

Ketimpangan distribusi PDRB antar provinsi sebelum reformasi nilai rata-rata adalah sebesar 0,5358 dan sepuluh tahun sesudah reformasi (tahun 2001 sd 2010) turun menjadi nilai rata-rata sebesar 0,503 . Tetapi nilai koefisien Gini sebelum dan sesudah reformasi masih diatas 0,4 yang memperlihatkan distribusi ketimpangan yang masih tinggi: (Todaro dan Smith 2006). 


\section{PENUTUP}

Keimpangan distribusi pendapatan antar wilayah dan provinsi di Indonesia sebelum otonomi daerah (1991 sd 2000) dan sesudah otonomi daerah (2001 sd 2010) dapat disimpulkan sebagai berikut: Pertama. Ketimpangan antar provinsi di Indonesia sebelum otonomi daerah dengan nilai rata-rata koefisien Gini adalah sebesar 0,5358 dengan nilai terendah 0,5034 pada tahun 1991 dan nilai tertinggi adalah 0,5803 pada tahun 1994. Kedua. Ketimpangan distribusi PDRB antar provinsi sesudah otonomi daerah (tahun 2001 sd 2010) memperlihatkan nilai rata-rata koefisien Gini sebesar 0,503 dengan nilai terendah adalah sebesar 0,426 pada tahun 2006 dan nilai tertinggi adalah 0,537 pada tahun 2001.

Distribusi ketimpangan antar wilayah dan antar provinsi di Indonesia sebelum otonomi daerah dan sesudah otonomi daerah masih tinggi. Hal ini terlihat berdasarkan koefisien Gini sebelum otonomi daerah adalah 0,5358 dan sesudah otonomi nilai ratarata koefisien Gininya adalah 0,503 Berdasarkan hal tersebut maka dapat disimpulkan masih terdapat distribusi ketimpangan antar wilayah dan provinsi di Indonesia sebelum dan sesudah reformasi kerena koefisien Gininya masih diatas 0,4 .

Terjadinya ketimpangan menurut Myrdal disebabkan oleh backwash effect tersebut dan perpindahan aliran modal dan tenaga kerja trampil ke daerah maju (inti) akan meningkatkan ketimpangan antar wilayah tersebut. Terjadinya ketimpangan distribusi PDRB antar wilayah sebelum otonomi daerah dimana 60,40 persen PDB Indonesia terkonsentrasi di wilayah Jawa dan Bali (tabel 1.1). Sesudah otonomi daerah kondisi tersebut tidak jauh berbeda yaitu 60,28 persen PDB Indonesia terkonsentrasi di wilayah Jawa dan Bali.

Backwash effect ini disebabkan wilayah Jawa dan Bali merupakan pusat pemerintah, perdagangan dan jasa, serta pusat industri pengolahan. Wilayah ini juga di dukung oleh infrastruktur yang relatih lebih baik dari daerah-daerah lain. Faktor tersebut akan menarik aliran tenaga kerja dan modal daerah-daerah lain sehingga terjadi konsentrasi kegiatan ekonomi di wilyah Jawa dan Bali. Konsentrasi kegiatan ekonomi pada wilayah ini menyebabkan konsentrasi PBRB di wilayah tersebut.

\section{DAFTAR RUJUKAN}

Aghion, P., \& Howitt, P. (1992). Endogenous Growth Theory, Cambridge, Massachusets: The MIT Press.

Akita, T., \& Alisjahbana, A.S. (2002). Regional Income Inequality in Indonesia and Indonesia Using Two-Stage Nested Theil Decomposition Method. Annal of Regional Science, Vol 37, 57-77.

Anwar.A. (2005). Ketimpangan Pembangunan Wilayah dan Pedesaan: Tinjuan Kritis. Bogor. P4W Press.

Bronzini dan Piselli (2006). Determinants of Long-Run Regional Productivity: The Role of R\&D, Human Capital, and Public Infrastructure. Bank of Italy Working Paper Number 597. September 2006.

Chenery, Hollis \& Srinivasan,T,N (1988). Hand Book of Development Economics. Elsevier Science Publisher B.V. Amsterdam.

Downs, A. (1957). An Economic Theory of Democracy, Harper and Row, Newyork. Greene, William H. (2012); Econometric Analysis, $7^{\text {th }}$ Eds., Pearson 
Glaeser, E. (2000). The New Urban and Economics Growth, dalam G.Clark,M.Gertler,\& M.Fldman, Hand Book of Economic Geography. Oxford. Oxford University Press. 8399.

Hendra Esmara. (1986). Politik Perencanaan Pembangunan: Teori, Kebijaksanaan

dan Prospek. Jakarta: PT. Gramedia. vol $11(1), 41-57$

(1975) Regional Income Disparities. Bulletin of Indonesian Economics

Hindriks, Jean and Gareth D. Myles. (2006). Intermediate Public Economics. Cambridge, Mass. : MIT Press.

Iyanatul Islam.(2003). Dealing With Spatial Dimensions of Inequlity in Indonesia: To A Social Accord. World Bank Working Paper. Washington D.C. June 9-10, 2003.

Jhingan, M.L. (2004). Ekonomi Pembangunan dan Perencanaan. Jakarta: Raja Grafindo Persada.

Jajri, Idris. (2007). Determinants of Total Factor Productivity Growth in Malaysia. Journal of Economic Cooperation. 28, 3 (2007), 41-58.

Lembaga Ilmu Pengetahuan Indonesia (LIPI), 2010. Kajian Penerapan TFP di Sektor Pertanian, Working Paper 2010.

Mankiw, N. Gregory, (2007). Macroeconomics. $6^{\text {th }}$ Edition. Worth Publishers. New York. Matsui Kazuhisa. (2003). Decentralization in Nation State Building of Indonesia. Institute of Developing Economies (IDE-JETRO) Research Paper No.2, August 2003.

Myles, Gareth D. (2001). Public Economics, G.D.Myles@ex.ac.uk.

Oates, W. (1999). An Assay on Fiskal Federalism. Journal of Economic Literatur, Americal Economic Assosiation, Vol. 37 (3).

Syafrizal (2008). Ekonomi Regional: Teori dan Aplikasi, Padang: Baduose Media.

Sumitro Djojohadikusumo (1994). Perkembangan Pemikiran Ekonomi: Dasar Teori Ekonomi Pertumbuhan dan Ekonomi Pembangunan. Jakarta: LPES

Todaro, Michael P. \& Smith, Stephen C (2006). Economic Development (haris Munandar). Edisi Kesembilan, Jakarta: Erlangga. 